\title{
HISTÓRIAS DENTRO DO FESTIVAL: Um retrato das 26 edições do Jaraguá em Dança
}

\author{
Nathã Luiz Schug ${ }^{1}$ \\ natha.admliss@gmail.com \\ Marco Aurélio da Cruz Souza² \\ $\underline{\text { marcoaurelio.souzamarco@gmail.com }}$
}

\section{RESUMO:}

O presente artigo tem como objetivo fazer um recorte das inúmeras histórias ocorridas durante as edições do Festival Jaraguá em Dança, evento realizado a mais de duas décadas e meia na cidade de Jaraguá do Sul, norte do estado de Santa Catarina. A pesquisa principal teve como seu objetivo relatar sobre as 26 edições do evento, onde que obtivemos relatos através dos participantes do festival, onde devidamente selecionados foram submetidos a perguntas em gravação de vídeo. Utiliza-se de uma poética de um conto/livro de história.

Palavra-Chave: História; Festival; Dança; Jaraguá.

\section{ABSTRACT}

This article aims to make a cut of the countless stories that occurred during the editions of the Festival Jaraguá em Dança, an event held for more than two and a half decades in the city of Jaraguá do Sul, in the north of the state of Santa Catarina. The main research had as it is objective to report on the 26 editions of the event, where we obtained reports through the festival participants, where duly selected were submitted to questions in video recording. It uses a poetics of a short story/history book.

Key words: History; Festival; Dance; Jaraguá.

\section{ERA UMA VEZ}

Este presente artigo foi elaborado a partir do capítulo 4 do Trabalho de Conclusão de Curso de Licenciatura em Dança da Universidade Regional de Blumenau, intitulado "Festival Jaraguá em Dança: 26 anos de histórias, comédias, aplausos e tragédias", elaborado por Nathã Luiz Schug com orientação de Ivana Vitória Deeke Fuhrmann. Este quarto capítulo dava visibilidade a micro histórias dentro que

\footnotetext{
${ }^{1}$ Professor/artista/pesquisador de Dança nas áreas do corpo, formado em Dança pela Universidade Regional de BlumenauFURB, Pós Graduando em Linguagens e Poéticas da Dança pela FFM de Blumenau- SC.

2 Doutor em Motricidade Humana na especialidade Dança pela Universidade de Lisboa - Portugal, coordenador do curso de Licenciatura em Dança e professor da pós-graduação Especialização em Linguagem e Poéticas da Dança, ambas da Universidade Regional de Blumenau (FURB), membro do conselho científico da Associação Nacional dos Pesquisadores em Dança (2019-2021) e do concelho editorial (2021-2023). Vice-presidente da APRODANÇA - SC (2019-2023).
} 
aconteceram dentro do evento, e foi chamado de "Histórias dentro do Festival". O TCC teve o intuito de organizar uma narrativa sobre a história sobre as 26 edições do festival Jaraguá em Dança, a partir de dados coletados através de entrevistas realizadas com Christiano Gourlart, Djuliano Gadotti, Egberto Saurini, Lisa Jaworski, Marilene Giese, Nathalia Luzia Petry, Sidnei Lopes e Silvia Kita. O acadêmico que realizou a pesquisa reflete:

\begin{abstract}
Ao pesquisar sobre um festival de dança que ultrapassa duas décadas de existência é comum que muitas situações ocorram por trás das cortinas. A vida é um caminho de fluxo único e o que faz com que ela seja mais densa de histórias ou não são as suas experiências, as inúmeras tentativas de buscar outras coisas e ocupar de forma proveitosa as 24 horas existentes em um dia. (SCHUG, 2021 p. 46)
\end{abstract}

Nesse sentido, iremos criar um diálogo com o referido capítulo do TCC, utilizando trechos em busca de uma poética de livro-conto com suas histórias enquanto bailarino e coreógrafo participante deste festival. Apresenta-se as "Curvas Dramáticas" que incluem micronarrativas que intitulamos de "as comédias" e "as tragédias" vividas no festival. Interligando também ao contexto pandêmico que a população dos anos 2020 e 2021 viveu, discutindo assim a "Coreografia 'Covid-19", mostrando as alternativas que foram buscadas para que a arte e o festival não se perdessem na história da cidade.

\title{
PERSONAGEM PRINCIPAL
}

Via de regra, toda história ou um conto, tem um personagem principal. Nesse texto, resolvemos que o personagem principal é um dos pesquisadores, Nathã Luiz Schug , por sua estreita relação com o Festival Jaraguá em Dança (JED). Ele agrega experiências no evento atuando em diferentes funções como: bailarino, assistente, instrutor/coreógrafo e agora, pesquisador dentro do festival. O Festival Jaraguá em Dança, (JED) é realizado na cidade de Jaraguá do Sul, no estado de Santa Catarina (SC). Em 1994 a Fundação Cultural de Jaraguá do Sul, órgão vinculado à prefeitura do município criou o evento através do Secretário de Cultura da época. Em primeiro formato, o festival era realizado no Ginásio de Esportes Arthur Muller, um espaço poliesportivo localizado no centro da cidade. Edições mais tarde, passou a ser realizado na Sociedade Cultura Artística (SCAR), onde segue até os dias de hoje. O evento possui uma duração aproximada de sete dias, anteriormente era organizado como um evento competitivo, dividido por categorias, faixas etárias e gêneros e regido através de editais e regulamentos. Por volta dos anos 2000, transformou-se em uma mostra, mantendo a configuração anterior. Milhares de bailarinos e coreógrafos passaram pelos palcos do Jaraguá em Dança em seus 26 anos de existência. Grupos convidados em diversas vezes foram convidados para fazerem a abertura das noites de 
Revista "O Teatro Transcende" Departamento de Artes - CCEAL da FURB - ISSN 2236-6644 -

Blumenau, Vol. 26, № 1, p. 117 - 128-(2021)

apresentações, como as companhias: Cia Millenium, Ballet da Cidade de São Paulo, Teatro Guaíra, Jair Morais, entre outros.

Ao entender o contexto do festival, começamos apresentando trechos do diário de bordo de um dos pesquisadores e nesse trabalho chamamos o "Eu, Bailarino" que tem por objetivo trazer a experiência concreta de um dos autores deste artigo, inspirando-se no "Esboço de Auto-análise" escrito por Pierre Bourdieu (2001). Nesse sentido, um conjunto de narrativas são organizadas no decorrer de suas participações em 9 das 26 edições do JED já realizadas, e criando um diálogo alinhavado com as pessoas entrevistadas.

Sendo assim, citamos o primeiro momento da sua inserção no festival, no ano de 2010, quando iniciou a trajetória dentro da Dança para a partir daí tecer outras relações com outras micronarrativas.

Estudava na Escola Municipal Gustavo Tank, na cidade de Guaramirim, onde uma turma de dança foi iniciada para participar de um festival de dança da região. 0 ano foi marcado por um campeonato mundial esportivo [...] portanto, a coreografia abrangeu a temática futebol. O professor que elaborou a coreografia tinha formação em Educação Física e, aparentemente, sua obra foi composta com uma conexão afetiva muito forte, contudo, não recebeu nenhuma colocação.

No ano seguinte, ingressei em outro grupo de dança escolar. Este tinha o intuito de participar do Festival Dança Catarina ${ }^{3}$, promovido pela FESPORTE - naquela situação atingimos segundo lugar. Posteriormente, entrei em uma instituição subsidiada pela prefeitura de Guaramirim, desta forma, conheci minha grande mestra, Stela Liss, que nos inseriu no Festival Jaraguá em Dança - este estava em sua $18^{a}$ edição e já se acontecia no Teatro da SCAR.

Esse primeiro contato com o JED foi mágico - levando em conta a emoção de qualquer primeira experiência de um adolescente de 13 anos -, tudo reluzia diante dos olhos. Questão comum para festivais, o tempo de ensaio prévio à apresentação no espaço - conhecido como "passagem de palco" era extremamente escasso, dificultando o processo de localizar-se em cena, afinal, o encantamento pelas cortinas, pelas luzes, pelos adereços, pelo linóleo etc., nos tiraram daquele local e nos levaram para um plano imaginário. Rapidamente, o professor chamava a atenção e retornava-se o foco para a missão de reproduzir aquilo que levamos meses para elaborar e horas de trabalho árduo para lapidar: a coreografia.

\footnotetext{
${ }^{3}$ O FESTIVAL ESCOLAR DANÇA CATARINA é uma promoção da Fundação Catarinense de Esportes (FESPORTE), Secretaria de Estado de Turismo, Cultura e Esporte, Governo do Estado, com apoio da Secretaria Estadual de Educação, das Secretarias de Desenvolvimento Regionais e das prefeituras.

Considerado o maior evento de Dança Escolar do Brasil, o Festival está em sua vigésima primeira edição e tem como principais objetivos fomentar a Dança na Escola e salvaguardar a educação integral da criança e adolescente na construção de sua cidadania. (FESPORTE, 2021).
} 
Para desenvolver a coreografia estudamos a técnica da dança jazz - dentro de uma instituição não formal que utilizava a metodologia tradicional para o ensino da dança bem como técnicas derivadas do ballet clássico, fazíamos exercícios de chão, de barra, de centro e de diagonal. Após várias semanas de treino, a técnica estava minimamente em nossos corpos, treinávamos nossas sequências coreográficas desenvolvidas pela professora para a composição, a fim de apresentar no Jaraguá em Dança.

Então, o grande dia chegou, figurinos postos, corações acelerados e a ansiedade tomava nosso corpo a cada grupo que se apresentava. Nossa vez estava a cada momento mais próxima. A hora chegou, a chamada do grupo foi feita, o público gritava e aplaudia - confesso ainda não ter ciência se esse comportamento estimula a confiança ou aterroriza ainda mais aquilo que já está em tensão. Cortinas abertas e luzes do palco apagadas. Auxiliares de palco ajudaram a posicionar cada um em suas posições. Apesar da escuridão, havia uma pequena compreensão das figuras que se formavam nas sombras. As únicas luzes acesas eram as da cabine de luz - localizada no fundo da plateia de forma centralizada - e as luzes das saídas de emergência (interessante seu posicionamento à beira do palco, visto que a insegurança gera uma vontade de fuga recorrente em nossa mente nos minutos que antecedem a coreografia).

As luzes tomaram intensidade aos poucos. A plateia se calou e as enormes caixas de som distribuídas pelo teatro começaram a executar uma música, que, felizmente, era da nossa coreografia o primeiro pensamento foi "Ao menos é a música correta, um bom começo".

Neste momento não existe fuga. Não adiantava fingir desmaio, correr para as saídas de emergência e afins, precisávamos confrontar nosso medo. Um trabalho em grupo, cada um com sua função, mas com único objetivo. Esse processo é parte da construção de um artista e principalmente de um ser humano. Não correr mediante o medo. Não é prejudicial apenas a si mesmo, mas ao grupo que sentiria o impacto da fuga. Os poucos minutos de coreografia pareceram segundos ao fim da trilha sonora. O corpo pausado em sua pose final espera as luzes apagarem o quanto antes para que 0 personagem seja rapidamente desmontado e o então sonhado agradecimento do artista ao público através de reverência seja realizado e assim o público possa demonstrar sua aprovação através de palmas que, unidas ao teatro lotado, ecoam por todo o espaço.

Como diz o ditado "missão dada, é missão cumprida". A mudança da "água para o vinho" acontece de forma totalmente inexplicável. O enorme medo, capaz de paralisar nossas pernas, foi transformado em uma enorme euforia, incapaz de ser mantida dentro de uma única pessoa. Rapidamente precisamos deixar os bastidores - ou coxias, como são comumente conhecidos - em silêncio para não atrapalhar o andamento das outras apresentações (ação realizada com dificuldade 
devido à euforia, mas acatada em respeito aos demais grupos) para nos direcionarmos à uma área secundária longe do palco para enfim comemorar. Esse espaço secundário na SCAR é nomeado Espaço Panorâmico. Nele pode-se contemplar uma visão da cidade em $180^{\circ}$ (cento e oitenta graus) à cerca de 25 (vinte e cinco) metros do chão. Nesse ambiente, com mais de $575 \mathrm{~m}^{2}$ (quinhentos setenta e cinco metros quadrados), os bailarinos e demais participantes da noite de apresentações se aquecem, fazem maquiagem, vestem seus figurinos e aguardam a chamada para os bastidores. É um espaço democrático e maleável, perfeito para socialização. Contudo, após a coreografia, fomos direcionados a retirar nossos materiais e então tomar diferentes rumos - encontrar nossos pais, entrar no teatro para apreciar os demais grupos ou tomar o caminho para casa sozinhos.

O Festival Jaraguá em Dança apresenta um ponto comum como qualquer outro evento do gênero: ser um local de reunião dos amantes da dança. É, também, uma fusão de sensações, motivações e, por vezes, intrigas. Todos que estão ali possuem histórias, experiências e objetivos que os inseriram ali, seja por amor à arte ou não.

Em minha primeira participação do JED, o evento já estava no formato de mostra não competitiva. Contudo, previamente, em passeios com minha mãe e/ou com uma amiga professora de dança, assistíamos às noites que então eram competitivas e ficávamos até o fim para verificar os resultados e assim aplaudir os campeões.

Apesar de o festival ter essa mudança de caráter em sua história, é um dos poucos festivais não competitivos que possuem uma larga duração de evento. O fato de continuar crescendo o número de participações anualmente é algo muito peculiar, considerando que não existe um incentivo financeiro (um prêmio) para participar, simplesmente o puro prazer em estar presente ou por vitrine cultural.

Nas primeiras edições, somente preocupava-me em dançar, chegar pontualmente, levar todo 0 figurino, dançar e ir embora. Ao iniciar um processo profissional com professor e coreógrafo, acabei por ocupar funções mais complexas. Meu foco deixou de ser simplesmente no ato de dançar, minhas chegadas foram antecipadas e minhas saídas tornaram-se mais tardias. Responsabilizei-me pelo acompanhamento dos estudantes quando a professora não podia e em casos mais recentes, acompanhei meus próprios alunos, e ajudei-os a controlar a ansiedade pelo qual já havia passado como bailarino e agora enfrentava enquanto coreógrafo.

Assistir meus alunos pela primeira vez foi uma tortura sem precedentes. Colocar meu trabalho à prova aliado à sensação de impotência caso algo não ocorresse como planejado me gerou grande agonia. Por uma escolha pessoal, levei-os até as coxias e no momento de sua apresentação direcioneime à cabine de luz. Fixei meus pés naquele local e sinalizei ao sonoplasta para dar o início da música. Os meus pés congelaram e minha respiração cessou. De início meus pensamentos preocupavam-se 
Revista "O Teatro Transcende" Departamento de Artes - CCEAL da FURB - ISSN 2236-6644 -

Blumenau, Vol. 26, № 1, p. 117 - 128-(2021)

com o movimento inicial, para que fossem executados como treinado - a sensação de impotência mencionada anteriormente[...]

A vontade de lecionar dança foi um desejo crescente após a abertura do curso de Licenciatura em Dança pela Fundação Universidade Regional de Blumenau em 2017. Entreguei-me nesse caminho e estou agora fazendo parte da primeira turma de formandos em Dança pela instituição. Em minha trajetória acadêmica, pude compreender minhas obras direcionadas ao JED a partir de um novo olhar, trazendo novas discussões e aprendizados nas minhas participações neste festival. (Trecho autobiográfico retirado do Festival Jaraguá em Dança: 26 anos de histórias, comédias, aplausos e tragédias, p. 46-50).Após essa narrativa descrita a partir da experiência de um dos pesquisadores, passamos a tecer relações com outras micronarrativas, com vistas ao processo que foi vivido por estas pessoas.

\section{CURVAS DRAMÁTICAS}

Como todo evento, é quase impossível não haver situações inusitadas que não foram planejadas nem pelos organizadores, nem pelos participantes. São situações reais, e por isso intitulamos de "Curvas Dramáticas", pelo fato da valorização de pequenos acontecimentos dentro do evento, que dão emoção e engajamento com a história maior.

Ao conversarmos com os participantes do estudo, detectamos que se referiam a tragédias e comédias em suas participações no festival. Ao analisarmos atentamente as descrições das entrevistas percebemos que se referiam a Tragédia (quando acenavam a um ponto negativo na visão dos participantes do estudo) e Comédia (quando acenavam a um ponto positivo na visão dos participantes do estudo). Apresenta-se aqui algum das contribuições.

Eu tive uma aluna minha que eu a preparei para uma variação, [..] a Fada Lilás [...]. Ela em sala de aula fazia tudo. Ela tinha um pedacinho que ela tinha um pouco de problema, assim, que tinha uma certa dificuldade, mas fazia tudo. Quando ela chegou no palco nada aconteceu. O primeiro passo que ela fez, ela já falhou e, assim, e foi falhando, foi falhando e foi... então você imagina na parte que ela tinha dificuldade. Assim, foi uma catástrofe. Muito difícil, né, esse momento. Difícil para ela, difícil para mim. Eu acho que mais... para a gente, né, porque a gente sofre mais, é, como coreógrafo como professor... E eu sou muito apegado aos meus alunos e eram um grupo que eu tinha que a gente era... Era muito unida, a gente viajava muito, a gente era muito unido. Assim, aquilo me fez sofrer demais, porque me fez questionar se eu tinha feito a escolha certa, é, de pôr uma variação tão difícil. E aí eu meio que questionava: ela fazia tudo em sala de aula, né, então você espera que às vezes fica nervosa que não chegue no mesmo nível, que caia um pouco, mas não tanto. $E$ aí foi um problema depois, porque toda a insegurança veio nela, como por ela para uma próxima apresentação. [...] eu sei, porque eu já... já aconteceu uma vez comigo isso no palco um ballet que eu dançava super bem... e uma vez deu tudo errado. [...] Você tem que dar um jeito, você tem que resolver. [...] Aí chegou a época de escolher tal, tudo... Aí eu fico: "olha vamos escolher juntos" e tal. Aí 
peguei a entrada de Kitri de Dom Quixote. Eu falei pra ela: "olha, você gosta dessa variação?". Eu sei que você vai me perguntar qual foram os melhores momentos e aí foi este o meu melhor momento, né. 0 melhor momento foi com ela o melhor momento foi com ela. Um dos... né. Teve diversos. Aí ela entrou e na sala de aula quando eu pus a música passei a coreografia, eis que na primeira vez que ela passou... Sabe o que é você ver que um trauma naquela passagem se dissipou, né, ela se sente extremamente segura com aquela variação. Sim, [...] foi impressionante. Só que quando chegou na hora de dançar no palco, né, em mim veio toda aquela coisa e eu na cabine de som super apreensivo, mas ela entrou e dançou como nunca tinha dançado. Então foi uma superação dela de trauma de palco, porque quem dança sabe que quando você tem um trauma no palco, é muito difícil você superar isso. [...] Por que de palco, né? Porque você não dança sozinho. Tem muita gente [...] esperando o melhor de ti, né. [...] Quando terminou a plateia veio abaixo. (informação verbal) ${ }^{4}$

Movimento como meio, a dança atravessa o mundo pelos palcos dos festivais. Erros e acertos são duas pontas que são divididas por uma linha tênue que se revezam em meio às apresentações. Entretanto a cada finalização de uma apresentação os erros acabam perdendo a pressão psicológica momentânea durante a coreografia, o ressurgimento da confiança do artista é um processo denso e complexo, mas não impossível.

A pior foi [...] eu acho que foi a primeira vez que eu dancei no estúdio que danço hoje, no Studio Liss, que era uma coreografia que eu já tinha acompanhado eles dançando por vídeo, já tinha visto apresentações deles né, daí foi onde eu me interessei pelo grupo. Aí quando eu cheguei já estava faltando um mês pro Jaraguá em dança, assim, daí eu ensaiei praticamente uns 4, 5 ensaios e já me botaram no palco para dançar. Aí pensei "vai dar tudo errado" e daí eu errei várias, várias sequências. [...] aí depois eu saí de lá fiquei sozinho pensando no meu cantinho, mas depois eu vi que era normal né, eu tinha pouca experiência na verdade, né, depois de muito tempo parado, aí acho que essa vez foi a que me tocou muito assim, porque eu me cobro muito e daí nesse caso ali não deu muito certo como eu tinha planejado, mas foi. (informação verbal) $^{5}$

A inexperiência em cima do palco dificulta o processo de aguentar a pressão psicológica que é exercida pelo público. Contudo, quando se está em conjunto, o mesmo transmite uma energia para continuar até o fim. $\mathrm{O}$ companheirismo é algo dentro dos coletivos que faz o ser humano tornar-se mais confiante, sociável e recíproco.

É, inusitado... tem algumas, né. Mas assim o que mais toca a gente é quando a pessoa que a gente tá lá dançando e a pessoa, a plateia, algum conhecido teu grita o teu nome grita o nome de estúdio e aquela energia gigantesca lá na plateia e daí tem algumas experiências engraçadas também que a gente dá risada de, por exemplo, de tombo ou do teu... de esbarrar no coleguinha e os dois esquecer a coreografia de repente. Essas experiências são meio comuns assim, né, não acontece muito comigo, mas como eu tô em cima do palco, eu vejo acontecendo no meio do grupo, no meio da coreografia, assim. Mas também já errei bastante, já trombei no colega, já entrei atrasado da coxia... Daí isso aí na hora dá um nervoso, dá uma agonia, mas depois tu sai e tu fica rindo, daí outra pessoa fala que também fez daí tu fica mais aliviado. (informação verbal) ${ }^{6}$

\footnotetext{
${ }^{4}$ Entrevista concedida por Egberto Saurini ao autor deste trabalho em 2021.

${ }^{5}$ Entrevista concedida por Djuliano Gadotti ao autor deste trabalho em 2021.

${ }^{6}$ Entrevista concedida por Djuliano Gadotti ao autor deste trabalho em 2021.
} 
Durante a produção de qualquer evento imaginamos todos possíveis tipos de problemas que podem ocorrer. Porém, há certas situações que vão além de inimagináveis, elas são incontroláveis. Como é o caso da energia elétrica. Algo tão comum, mas com uma importância tão grande que sem ela nada mais acontece normalmente.

[...] nem sempre foi um mar de rosas, né, eu acho que o momento mais tenso, assim, que eu vivi até hoje na minha vida no Jaraguá em dança foi um ano - não vou saber precisar o ano quando ainda no Arthur Muller, a gente tava no meio do festival - sei lá, 5000 pessoas lá dentro do ginásio - né, a gente fazia aquele "tabladinho" todo na quadra. E, de repente, no meio do festival, "puf*, saiu a energia. E tudo virou breu, tudo ficou escuro, é... na época a gente não tinha gerador. Ficou tudo escuro e aí bateu aquele desespero a gente não sabia o que fazer. (informação verbal) ${ }^{7}$

\section{Fotografia 1 - 5 edição JED, Grupo Galpão Saúde}

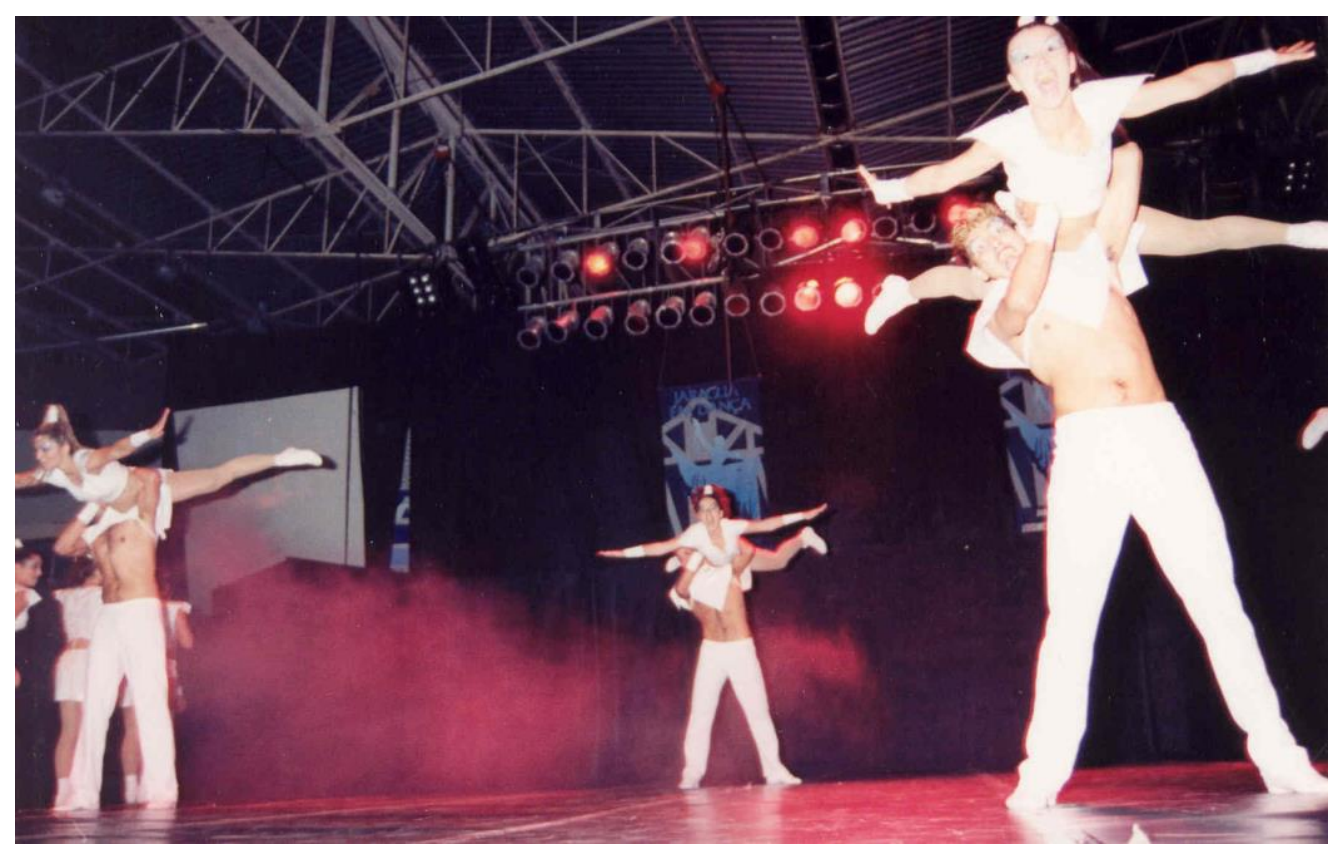

Fonte: Arquivo Histórico de Jaraguá do Sul (2021).

Nós, como eu coloquei, a gente tem dentro do evento né, por exemplo (inaudível) [...] nós já estamos planejando, agora estamos no mês de abril, já começamos desde o mês de março a planejar o Jaraguá em Dança lá para setembro [...]. É um evento que você termina um, né, você já começa aos poucos planejar o próximo e quando se trata o setor público isso é um pouco mais complicado, né. Quando você faz um evento de particular você tenha um orçamento $X$, você faz os orçamentos, você contrata as pessoas que mais se adequam com o seu evento [...]. Dentro do setor público, você... Tudo tem que fazer concorrência licitação, é pregão, uma série de atividades que acabam engessando, né, um pouco este evento. Então, assim, nós temos que ter expertise muito grande naquilo que a gente quer elencar para 0 evento. Então, assim, é um pouquinho mais complicado fazer cultura dentro do setor público devido à essas amarrações, mesmo assim temos que achar as maneiras para que essas as coisas aconteçam da melhor forma possível. Em um desses... dessas amarrações públicas

\footnotetext{
${ }^{7}$ Entrevista concedida por Marilene Giesse ao autor deste trabalho em 2021.
} 
nestes editais nestas questões assim, nós estávamos no Jaraguá em Dança no Ginásio Arthur Muller, nós tivemos uma situação com a questão do som e luz. Como eu falei anteriormente tudo dependia muito de licitação de empresas que iriam para a concorrência para montar luz, montar som, dentro do Ginásio Arthur Muller, para que o evento pudesse acontecer. E nós lançamos o edital dentro do tempo, né, de som e luz, e nós tivemos em primeiro momento uma empresa impugnou, entrou com recurso, alegando que algo não estava correto, e daí você tem que abrir novamente e daí tem o prazo de 30 dias para um outro edital, e daí uma outra empresa impugnou, daí isso aí é mais 30 e de repente estava chegando na semana do evento e nós ainda com aquele edital enrolado, não podíamos fazer, se não tínhamos som e luz ainda para o evento. Daí processo jurídico envolvendo a procuradoria do município para tentar liberar. Aí os dias do Jaraguá em Dança chegando e nada de nós termos a empresa de som e luz. Foi um momento muito tenso, além daquele dia que faltou luz no ginásio [...]. Isto na quinta-feira da semana anterior ainda não tínhamos o resultado até conseguimos através do jurídico uma... algo lá que liberasse a contratação da empresa vencedora, né, para que pudesse fazer o evento. Isso na quarta-feira antes do evento, então o pessoal passou o dia todo ai montando o evento, montando luz e som na madruga, a gente acompanhando. Esses são os momentos de tensão [...]. Porque um evento nesse porte não diz respeito apenas ali a quem está... que são os pontos... o ponto principal que é chave mestre, né, no evento que é o coreógrafo e o grupo de dança, mas tudo que envolve, né. Assim, nesse ponto como to colocando, nestes perrengues, né, então assim ó, quando você faz um evento desse porte é segurança, é limpeza, é questão de ingresso, quantas pessoas a gente consegue colocar. (informação verbal) $^{8}$

Extremamente burocráticos, os processos públicos são exatamente isto. Possui um conceito, um porque para a existência das licitações. Por lidar com dinheiro público, espera-se que no mínimo o gestor responsável não cometa corrupção como por exemplo, o superfaturamento os produtos. Do mesmo jeito que a burocracia garante a transparência do serviço público, em alguns casos ela acaba sendo uma grande vilã.

Como eu falei anteriormente, assim, como eu tive essa experiência de participar das competições - quando teve competições -, é, essa sensação, não foi legal assim, de perceber o... Até porque, assim, para... naquele momento que aconteceu aquele evento, que a professora a coreografa do colégio particular não quis buscar o troféu de segundo lugar, é... foi muito, né, "como assim uma escola pública, é, ganhar o troféu de primeiro lugar, e uma escola particular que é uma professora que já tem referência não conseguiu o primeiro lugar?", então... e assim... e foram... Foi um momento, assim, pra mim marcou bastante. A gente ficou muito feliz de ter conseguido o primeiro lugar, mas assim ao mesmo tempo fiquei muito, muito, muito triste de ter vivido essa situação, né, de ter esse preconceito, assim, de falar com uma escola pública pode ganhar de uma escola particular né? (informação verbal) ${ }^{9}$

A ética na profissão de coreógrafo, não é algo que é moldável de forma rápida e simples, é necessário ter humildade e abertura para aprender sempre. Infelizmente, o episódio com a "profissional" mostra pré-conceitos sociais, não algo ligado diretamente a dança, e sim a outras formas préconceituadas exercidas na sociedade em sua formação.

Eu ainda tenho as minhas críticas, né, a alguns profissionais que ainda que ainda não respeitam esse espaço de dança, não respeitam no sentido, assim, de não aprofundar sua pesquisa, não trabalhar o máximo do seu aluno, de levar de repente qualquer coisa para cima do palco, ou às vezes, leva um figurino deslumbrante e a dança não acontece sabe, você assiste e fala "nossa, que lindo o figurino". Cara, "que lindo figurino", legal, e aonde está a dança desse lindo figurino? Então, ainda temos muitos profissionais que trabalham dessa

\footnotetext{
${ }^{8}$ Entrevista concedida por Sidnei Lopes ao autor deste trabalho em 2021.

${ }^{9}$ Entrevista concedida por Elisangela Jaworski ao autor deste trabalho em 2021.
} 
maneira, assim, que eu acho que ainda falta essa reciclagem, essa busca de informações, e que ainda pensa que o figurino, a foto, a luz, o palco é o que define o seu trabalho e na verdade eles são complementos né? Mas a dança, a alegria de ver a criança dançando feliz em cima do palco, eu acho que isso é o mais importante. $E$ aí a gente ainda tem alguns profissionais que ainda pecam nesse sentido. A dança fica muito num segundo plano e figurinos de cabelos por tudo okay, tem uns então nesse sentido. (informação verbal) ${ }^{10}$

Marques (1996) faz referência a cópias em cima do palco agregando ao que a entrevistada menciona sobre o foco fora do movimento. Temos ciência o quanto é importante a iluminação, a maquiagem, o figurino e demais acessórios junto às obras coreográficas. Por outro lado, é necessário entender que a dança não é somente o figurino, não é exclusivamente só o cenário, não é dependente da maquiagem elaborada, e sim movimento de união ao contexto ao que quer transmitir. Ganhar atenção momentânea pela estética cênica não faz o grupo ser o melhor. No tempo presente, por mais leiga que a sociedade interaja em assuntos de dança, sua autonomia crítica é ativa para avaliar e "colocar na balança" que adereços não ganham de um movimento bem-feito e planejado.

Quando a dança é ensinada nas escolas e fora delas, ainda segue o conceito de ensino e da arte do século XVIII, seja essa dança uma dança "dos alunos" (danças urbanas, por exemplo), da mídia, ou um repertório de danças populares brasileiras. Nesses casos, a dança aparece como sinônimo de repertório acabado, passos sequenciados a serem copiados e apresentados. Há também escolas que já trabalham com possibilidades de compreensão do corpo, de criação e produção de dança, com produções artísticas que, não raramente, caem no laissez-faire artístico das décadas de 1960-70. O conceito de arte e a forma de ensiná-la nas escolas formais - e em inúmeras situações de ensino informais também - encontram-se, ainda, em grande parte, estanques e anacrônicas (MARQUES, 1996).

\section{COREOGRAFIA "COVID-19"}

A pandemia mundial causada pela SARS-CoV-211, no ano de 2020, forçou a $26^{a}$ Edição do Festival Jaraguá em Dança sofresse alterações para sua realização e alterou para funcionar de forma remota. O comitê organizador reelaborou-se para que os grupos interessados em participar da edição pudessem cadastrar suas coreografias, e uma logística para que respeitasse as normas sanitárias vigentes, foi elaborado um regulamento estipulando o número máximo de bailarinos e diretrizes para gravação e organização dos grupos. O evento foi divulgado e transmitido através de canais da Prefeitura Municipal.

\footnotetext{
${ }^{10}$ Entrevista concedida por Elisangela Jaworski ao autor deste trabalho em 2021.

${ }^{11}$ A Covid-19 é uma infecção respiratória aguda causada pelo coronavírus SARS-CoV-2, potencialmente grave, de elevada transmissibilidade e de distribuição global. O SARS-CoV-2 é um betacoronavírus descoberto em amostras de lavado broncoalveolar obtidas de pacientes com pneumonia de causa desconhecida na cidade de Wuhan, província de Hubei, China, em dezembro de 2019. Pertence ao subgênero Sarbecovírus da família Coronaviridae e é o sétimo coronavírus conhecido a infectar seres humanos. (SAÚDE, 2021)
} 
Em 2021, a previsão da realização da $27^{\text {a }}$ Edição está prevista para meados de setembro. A Secretaria Municipal de Cultura, Esporte e Lazer estuda alternativas para a realização do evento. Em primeira opção - a mais otimista - é voltar a fazer de forma presencial, esperando uma redução das restrições vigentes. A segunda é executar novamente o sistema de organização de 2020. Sendo que a SEMCEL disponibiliza o teatro da SCAR com toda sua estrutura completa para as gravações onde estas serão reproduzidas na internet na data do evento. E como plano C, é idealizado a realização de uma formação para professores e bailarinos a fim de trocar experiências entre os participantes.

Apesar da dedicação total da SECEL para a realização do Festival na sua forma remota, ela acaba não suprindo certas necessidades dadas como "essenciais" na visão do artista. A ausência da plateia, das torcidas, dos relacionamentos e das trocas de experiências entre os participantes é comparado com um ensaio qualquer, onde um olhar externo é nulo. Isso pode ter sido um dos motivos no qual justificam a redução da participação de grupos na $26^{a}$ edição, além, óbvio da própria pandemia e do cenário econômico geral.

\section{FECHAMENTO DA HISTÓRIA}

Após esse recorte feito sobre essas histórias dentro do festival Jaraguá em Dança chegamos à conclusão que do mesmo jeito que há momentos cômicos, nos surpreendeu algumas situações no qual deixa em questão reflexões sobre a formação ética e profissional que cada indivíduo passou e o exemplo que ele deixa aos seus estudantes. 0 lado positivo de todos os revezes é que eles servem de padrões para um aprendizado maior, melhorar cada vez mais, evoluir sempre, porém considerando que todas essas transformações não ocorram da noite para o dia. Possuindo ciência que o festival se encaminha para sua $27^{\circ}$ edição, os organizadores entendem que existem muitas coisas a melhorar, porém 0 evento alavancou muito nestas quase três décadas de percurso. Todos os envolvidos no festival, também reconhecem sua notável importância na construção do artista e ser humano sensível, como já destacado no trecho do "eu, bailarino".

Como toda história que possui um começo, meio e fim, e nesse sentido, este capítulo intitulado "fechamento da história" remete a sensação de uma finalização de algo, uma história sem finalidade, entretanto como também nos contos, toda história pode haver uma continuação mesmo após a finalização do trecho. Trazendo para o contexto desta pesquisa, tendo total noção que haverá inúmeras edições durante os próximos anos, fica então a pergunta, será mesmo o...

\section{FIM?}

(Ou só um começo da contação destas micro histórias?) 


\section{REFERÊNCIAS}

BOURDIEU, Pierre. Esboço de auto-análise. Tradução, introdução, cronologia e notas Sergio Miceli. São Paulo: Companhia das Letras, 2005. - 140 p.:il.

FUNDAÇÃO CATARINENSE DE ESPORTES (FESPORTE), Festival Dança Catarina: O Projeto. 2021, Disponível em: http://www.dancacatarina.com.brl. Acesso em 22 de abr. de 2021.

GADOTTI, Djuliano. Festival Jaraguá em Dança- Entrevista 08- feat Djuliano Gadotti. Entrevista concedida a Nathã Luiz Schug, Disponível em: https://youtu.be/aEoPCNiPIql.

GIESSE, Marilene. Festival Jaraguá em Dança- Entrevista 01- feat Marilene Giesse. Entrevista concedida a Nathã Luiz Schug, Disponível em: https://youtu.be/L89jdMZmve0.

IBGE - INSTITUTO BRASILEIRO DE GEOGRAFIA E ESTATÍ́STICA. Pesquisa Nacional por Amostra de Domicílios: CENSO Jaraguá do Sul. Rio de Janeiro, 2010.

INFOPÉDIA, Comédia. Porto: Porto Editora, 2003-2021. Disponível em: https://www.infopedia.pt/\$comedia Acesso em 26 de Mar. de 2021.

JAWORSKI, Elisangela. Festival Jaraguá em Dança- Entrevista 01- feat Lisa Jaworski. Entrevista concedida a Nathã Luiz Schug, Disponível em: https://youtu.be/xyvYIYrPOXM.

LARRAIN, América. 0 negócio da arte e da cultura: para uma antropologia do Festival de Dança de Joinville. 2008, Dissertação (mestrado) - Universidade Federal de Santa Catarina, Centro de Filosofia e Ciências Humanas. Programa de Pós-Graduação em Antropologia social, Florianópolis, 2010 Disponível em: http://repositorio.ufsc.br/xmlui/handle/123456789/91636. Acesso em: 23 set. 2020.

LOPES, Sidnei. Festival Jaraguá em Dança- Entrevista 04- feat Sidnei Lopes. Entrevista concedida a Nathã Luiz Schug, Disponível em: https://youtu.be/5XloxH9rWF8.

MACHADO, Christiano Goulart. Festival Jaraguá em Dança- Entrevista 05- feat Christiano Machado. Entrevista concedida a Nathã Luiz Schug, Disponível em: https://youtu.be/NaRdOTSzqMY.

MARQUES, Isabel, Dança no contexto: uma proposta para a educação contemporânea. Tese (Doutorado). Faculdade de Educação da USP, 1996.

MINISTÉRIO DA SAÚDE, Coronavírus (COVID-19): Sobre a doença, 2021, Disponível em: https://coronavirus.saude.gov.br/sobre-a-doenca Acesso em 22 de abr. de 2021.

PREFEITURA DE JARAGUÁ DO SUL, História da cidade, Disponível em: https://www.jaraguadosul.sc.gov.br/apresentacao-secel. Acesso em 02 de out. de 2020.

SAURINI, Egberto. Festival Jaraguá em Dança- Entrevista 07- feat Beto Saurini. Entrevista concedida a Nathã Luiz Schug, Disponível em: https://youtu.be/n2Ch3EggODE

SCHUG, Nathã Luiz, Festival Jaraguá em Dança: 26 Anos De Histórias, Comédias, Aplausos e Tragédias, 2021, Trabalho de Conclusão de Curso, Graduação em Dança, Blumenau, 2021, Centro de Ciências da Educação, Artes e Letras, Prof ${ }^{\circ}$. Ms. Ivana Vitória Deeke Fuhrmann, 111p. CAAE: 42514820.0.0000.5370. 